\title{
Collaboration to Increase Women's Political Participation in East Kalimantan Governor Election
}

\author{
Ida Wahyuni Iskandar ${ }^{1}$, Zaid Bin Ahmad ${ }^{2}$, Adlina Binti Abdul Halim ${ }^{3}$ \\ \{idaharsono77@yahoo.com $\left.{ }^{1}\right\}$ \\ Universitas Mulawarman, Indonesia ${ }^{1}$ \\ Universiti Putra Malaysia, Malaysia ${ }^{2,3}$
}

\begin{abstract}
Democracy is the government's system to embody political process in the election. Historically, women's inequality in political power and participation in democracies. While woman in East Kalimantan find themselves under represented due to lack of participation woman at every socio-political. Due to every party has their own limitations, collaboration is very important in order to increase women's political participation. The regional head elections in Indonesia especially in East Kalimantan in general still found problems regarding the lack of women's political participation. This paper attempts to study to increase political participation among women in Indonesia specifically in East Kalimantan will be taken as a case study. The study employed a qualitative approach as well as interviews with relevant key informants. The efforts to increase woman's participation in politics certainly need systemic collaboration from the government, political parties, and community organization. Community organization activists in various regions in East Kalimantan can be involved in cooperation to increase woman political participation. Collaboration through political education in East Kalimantan is expected to increase woman's political participation in various forms such as voting, campaigns, political discussions, contacting regional heads or government, and even woman becoming candidates in elections.
\end{abstract}

Keywords: Pilkada, Political Participation, Women Participation

\section{Introduction}

Local-level democratization is very important in the Indonesian case because it is a vast country consisting of many regions with economic, social and cultural diversity [1]. By allowing the regions (province and regency/city) to running their own affairs, it was expected that the local people would benefit from the local government policies. Decentralization is a big and necessary step to maintain local democracy because it opens up space for local communities to be more active in political participation in their regions [2].

The community's participation in an election is very important because democratic theory states that community know what they need and their participation determines elected leaders and policies. The democratic system respects and upholds the rights and freedoms of community. Since it is an essential component in representative democracy, there is no democracy without community's political participation. It is also an indicator of governmental legitimacy, citizens' acceptance, the sense of mutual obligation and civic duty associated with existing and stable democracies [3]. 
Democracy recognizes the citizens' rights to negotiate with governing bodies through voting, campaigning, candidacy, occupying political office and lobbying individually or collectively [4]. Democracy gain opportunities for citizens to deliver their problems and aspiration to government or decision makers and effectively seek information about people's concerns [5]. Through democracy, citizen members have the opportunity to consider decisions that affect all citizens. In the decision-making process, every citizen must have the same rights. However, in reality, women's opportunities to use these rights are generally not optimal. Despite legal guarantees of political equality, women in many countries face political inequality in elected office, bureaucratic office, or day-to-day political participation.

Women's participation in the front line of democracy, peace and reconstruction efforts continues to gain recognition, leading to efforts by governments, political institutions, multilateral institutions, complemented by civil society organizations (CSOs), and individuals to realize these potentials. The truth, however, is that the number of women in politics is still below expectation [6]. In many studies, women are seen to have fewer resources of time, funding, social skills, and they are perceived to have less psychological engagement in politics than men [7].

Indonesian women emphasize the importance of women's political participation so that women's issues, people's welfare, and the nation's standard of living become attention. 'Women have needs that are better understood by women themselves. Women are considered more understand issues of reproductive health, family welfare, child welfare, children's education and household chores' [8].

Changes from centralization to decentralization also affected the electoral process. The regional head is currently directly elected by the community through regional elections. Pilkada (Pemilihan Kepala Daerah) or elections of regional held in Indonesia for just over 15 years. Since 2005, direct elections for provincial governors, district heads, and mayors were held throughout Indonesia. In 2008, the East Kalimantan General Election Commission (KPU) held the first direct Regional Head General Election. In first election there are four candidates for Regional Heads, including Nusyirwan Ismail and Heru Bambang, Awang Farouk Ishak and Fariz Wazdy, Yusuf SK and Luther Kombong, Achmad Amin and Hadi Mulyadi,. In 2013, the second election there are three candidates including Awang Faroek Ishak and Mukmin Faisyal, Farid Wadjdy and Sofyan Alex, Imdaad Hamid and Ipong Muchlissoni. The third election in 2018 there are four candidates as Regional Head including Andi Sofyan Hasdam and Rizal Effendi, Isran Noor and Hadi Mulyadi, Syaharie Jaang and Awang Ferdian Hidayat, Rusmadi Wongso and Syafaruddin,

Until the last governor election in 2018 , there are no women who can participate in the election as a candidate for regional head of East Kalimantan. Apart from voting, there are various political participation form in PILKADA (Local Government Election) such as campaign, political discussion, contacting, funding, etc. [9].

Generally, the participation of women in East Kalimantan still limited to the form of giving their vote in regional elections. Women's community has plenty of free time to take part in campaign stages, in order to increase the mass so that the campaign looks crowded. However, the opportunity to convey thoughts in the campaign for women was still lacking or was not given the opportunity to be involved. The access to political participation that influences policies that will be carried out by regional heads for example through political discussion and contacting is still limited. (there is a slight editorial change)

Exclusion based on religion or gender in politics has led to the fact that leader roles and decision-making bodies have historically excluded women. Yet, women can also be involved in politics, as long as they often fill non-strategic roles, or implementation positions distinct 
from decision-making positions. In addition, due to stereotype, when women are in leadership positions in party committees, they are often assigned positions which is deemed suitable for them. For instance, they are assigned to occupy the position of a consumption division in charge of the committee responsible for food and drink for events and meetings. In election, men and women have the same rights. But in East Kalimantan, women's political participation in various literatures are still considered lacking.

The efforts to increase women's participation in politic are not only the responsibility of one party. Each party has their respective limitations in carrying out sustainable political education programs. For instance, limitations in funding, human resources as program implementers, closeness to the community, and others (details are in the results or discussion section). Apart from the programs carried out by each organization, collaboration between the government, political parties and community organization is crucial.

\section{Methodology}

The research used a qualitative approach. This approach was obtained through women's political participation in East Kalimantan Governor Election (Pilkada) 2008-2018. The sampling technique is non-probability sampling. There are 14 (fourteen) informants selected based on purposive sampling who pose the following criteria:

a) Women community organization activist in East Kalimantan.

b) Women in government agency who know about women political participation in East Kalimantan.

c) Women who active in political party in East Kalimantan.

Unit of analysis in this paper is groups that contain of women's community organization, women's empowerment government agency and political party. This paper examine data about each group program, challenge and collaboration in increase women's political participation.

Data collection methods used in this study includes:

a) Literature studies/documents, using various sources from journals, books, research paper and media with relevant research topics. Document/archive study also conducted to obtain secondary data.

b) In-depth Interviews, this research using purposive random sampling methods, with selected informants. Interviews were performed using semi structured interview.

\section{Result and Discussion}

The data from the results of the National Social Economic Survey (Susenas) in September 2018 released by BPS (Indonesian Statistics Agency) of East Kalimantan revealed that there is a gender gap in the participation of meeting activities in the residential area which is quite high between men and women. The percentage of male population participating in activities meetings were much higher than that of women (32.5\% compared to $12.5 \%$ ). The finding confirms that the patrilineal culture which is adopted by the people of East Kalimantan still strongly exists. In such a culture, men are considered more entitled to play a role in decision making and more people are encouraged to participate in the meeting activities. This culture also influences women's political participation, including in political meetings or discussions. 
There are some strategies to overcome challenges to increase women's political participation [10]. First, reviewing all legal regulations that are inconsistent with the principle of gender justice. Second, the more critical political participation of women in general elections to choose leaders who care for the people. Third, increasing political education to community is as voters through independent civil society organizations.

It is very important that this strategic requires cooperation from various parties so that in addition to legal products from the government it can protect women's political participation rights and political education.

Women who will be voters in general elections, they need to be given political education as well so that they only choose candidates for the legislature or elect regional heads who are qualified and have a gender perspective. Some material that needs to be conveyed to women voters such as:

a) Information about the objective conditions of women's participation and representation in politics currently.

b) Information about women's human rights including women's political rights and how to use these rights.

c) Knowledge of women's roles and gender issues in politics including introduction to the concept of gender, the concept of gender equality and gender justice.

d) Information regarding laws relating to the political field.

e) The importance of choosing a political party that has a gender perspective and knows the consequences of that choice [11].

With regard to political education, the General Election Commission (KPU) has the responsibility to carry out the socialization of the implementation of elections to the public as stipulated by the Law. The role of the KPU in political socialization is affirmed in Election Law No. 22 of 2007 concerning Organizers of General Elections in article 8 paragraph (1) letter q: conducting socialization regarding the holding of elections and or relating to the duties and authority of the KPU to the public.

Political socialization usually only held during elections periods. Generally, the material presented was about election technical matters such as introduction of candidates for governor and voting methods.

Socialization is not just socialization that touches on procedural aspects such as the stages of electoral technical elections, but also substantive aspects such as explaining the benefits and importance of an election, also the formation of intelligent voters [12]. Governments and related authorities may perceive an education for critical political participation which linked to critical historical awareness as politically undesirable. Women must receive adequate voter education as well as political education in order to have a gender perspective. Women must be aware of their rights and equal opportunities to participate in politics. This is very important so that women will have the ability to fight for women's aspirations and interests to the fullest.

One of the political education programs for women from the government is conducted by the Office of Women's Empowerment and Child Protection. Reducing political inequality for women is one of the ministry's priority programs for empowering women and children. The program was supported by the Office of Women's Empowerment and Child Protection in areas including East Kalimantan. The program is also a priority program for regions with various activities. "Nationally, our ministry program is actually backing up with our program activities in the area. We have a $3 \mathrm{~N}$ program named. $3 \mathrm{~N}$ is ending violence against women, ending trafficking, ending women's economic disparities and ending the political gap for women" said the Office of Women's Empowerment and Child Protection East Kalimantan 
Efforts to increase the participation of women are also carried out by training programs by the government. Every year, this program is held. Political parties, beginner voters, community institutions are invited to this training. Various materials were given, such as how to campaign, how to decide the concerns posed to count votes during the election. This training has a training guideline module that has been prepared by the Ministry of Women's and Children's Empowerment. Often the figure who appears in the public does not know the theories given in the training and is written in the module.

The participation of activist political parties and community organization in this program has not been evenly distributed. The government sent out invitation to political parties but in fact there were women party activists who were not aware of this program. Without good cooperation of various parties, the effectiveness of political education will decrease.

Political parties as the main stakeholders related to women's participation have responsibility for agendas to achieve ideal conditions for women's representation in the political field, starting from regeneration, recruitment, political education for women [13]. Political parties do not only rely on the government for the implementation of political education programs. Without efforts from various parties, efforts to increase women's political participation will not run optimally. The political education that has been provided by the East Kalimantan government is deemed lacking. There are still many women who do not understand political participation, some have never participated in a political education program. Political parties must also play a role in efforts to increase women's political participation through various programs, one of which is political education. In addition, the party also has an obligation to provide political education. However, the role of the party has not been effective. The limited human resources in the party is one of the reasons. Not all members of political parties are active in organizing party programs during non-election periods. Thus, collaboration is very important so the role of political parties in increasing political education, especially for women, can be carried out. This collaboration can be between political parties and the government as well as community organizations in East Kalimantan

One of the IWAPI (Ikatan Wanita Pengusaha Indonesia) administrators who had been active as a cadre of political parties said there was a decline in the regeneration process. She used to be a speaker in cadre training at the party. She conveyed her experience while active in the party so that it could become learning. The decision to choose who will advance in the election also involves cadres. But now many candidates for people's representatives are advancing without a regeneration process. She thinks as if the party has ignored regeneration. Sharing experiences seem to have been ignored according to her. Apart from socializing to society, political education activities within the party must also be carried out. Political parties are important to increase the political participation of their cadres. After having knowledge and experience, cadres of political parties can also become political education trainers for new party cadres and the wider community.

Through good political education and cadastral processes, political parties are expected to be able to produce female cadres who are gender sensitive. Cadres who are not only busy fighting for personal and party interests. Women's participation is not just a quantity that meets the $30 \%$ quota target, but women must also have quality that shows that women are able to channel people's aspirations. Participation of female cadres who are active in efforts to increase community participation.

Programs to increase women's participation will be more effective if they cooperate with community organizations. Women tend to be more easily invited to participate if the program is part of their organization. Community organization activists can become agents of change to 
increase the participation of women who are members of their organizations. The governments and political parties can also work together with the community organizations to provide political education to members of the organization and the wider community [9].

Various women's organizations are struggling to increase women's political participation by holding voter education programs. This program explores not only political and cultural factors, but also religious factors affecting the political positions of women. In order to increase the consistency of their involvement in politics, these groups encourage women to use their political rights which will have an impact on daily life.

Community organization activists can become agents of change to increase the participation of women who are members of their organizations. Public participation also plays a role in a new arrangement to 'join-up' local governance processes, with community representation in Local Strategic Partnerships [14].

Women and men can gain social skills in nonpolitical voluntary associations such as community associations, religious organizations and trade unions. Nonpolitical voluntary associations provide community the opportunity to participate and organize activities. By participating in various activities in these organizations, citizens can develop organizational and communication skills. In addition, these organizations can provide social networks to encourage their members to be more active in political participation. These organizations provide opportunities to political discussion among members. Women's higher participation in religious organizations such as Aisyiyah and Muslimat NU can increase the chances of active participation in politics. Women gain social networks and leadership skills in nonpolitical voluntary organizations that will increase their political participation [15].

Based on data from the National Socio-Economic Survey (Susenas), conducted in September 2018 by BPS (Indonesia Statistics Agency) of East Kalimantan, the most memberhaving organizations were engaged in the religious sector $(40.52 \%)$ and the social sector $(21.43 \%)$. The urban population who participated in the activities of religious and social organizations were $37.88 \%$ and $19.41 \%$ respectively. Meanwhile, the inhabitants in rural areas were $46.67 \%$ involved in religious activities, and $26.14 \%$ in social sector. Religious organizations were mostly followed by the people of East Kalimantan in both urban and rural areas since these organizations can play an important role to encourage their members to participate in politics at least by casting vote in elections.

The most member-having religious organizations in East Kalimantan are Muslimat NU and Aisyiyah. Women's religious organizations encourage their members to participate in politics, at least use their right to elect regional heads through voting. Muslimat NU and Aisyiyah are neutral organizations, they do not support one candidate for regional head. Their members are free to have their own choice of regional heads.

One of the events that Aisyiyah held was the Seminar on Advancing Women's Political Education which took place at the mayor's office in Samarinda City. The political education seminar was intended to provide provisions for East Kalimantan women to be smart in responding to politics. The event was attended by 235 female students; universities students and administrators of the autonomous Muhammadiyah organization. According to the interviewees Mrs. A as the committee, Muslimat NU has also held political education which was attended by its members.

An organization's active role in getting its members to participate in voting can help increase the turnout rate in elections. Especially if the organization has branches in various regions. Aisyiyah and Muslimat NU can have an important role in the isolation of their members to participate in the regional head election process. 
One of the community organization that fights for women's political participation in East Kalimantan is NAPAS (Equivalent Women's Instinct). NAPAS provides political education to activist cadres. They are also given the ability to organize. Organizational skills are needed so that activists are able to pass on their knowledge of political education to the wider community who still lacks of political participation. This process does not have and requires a process of time.

Community organization that fights for women's political rights are the East Kalimantan Women's Caucus (Indonesian Political Women Caucus). Women's Caucus has members of various backgrounds. This organization carries out educational, awareness and advocacy efforts on the interests of women in politics.

One of the managers of the East Kalimantan Women's Caucus said that in fact, many women activists active in various organizations had the potential to jump into practical politics. However, many women had a dirty image of politics. They prefer to criticize the government indirectly. The Women's Caucus seeks to invite these activists to be directly involved in politics so that their aspirations are more easily responded. Female leaders in East Kalimantan communities sometimes have doubts about their own capacity. These doubts can affect the wider society's acceptance of women leaders. In fact, in democratic system, women are regarded no more as a political object. Therefore, many political parties admit that women actually have an appeal in the political sphere and are able to play an important role in the public sphere.

From interviews with women activists, the political education held by community organizations, for example Aisyiyah, Muslimat NU, NAPAS, the Indonesian Political Women Caucus in East Kalimantan does not have a structured module on some material that needs to be conveyed to women voters so does not have standard and clear guidelines regarding women's political education with a gender perspective. The use of modules can collaborate with the government. The government have modules that are quite complete but its usage is still not evenly distributed.

Many political education programs held by community organizations are not held regularly, programs are only held near the election period. Limited fund is one of the issues of community organizations to carry out sustainable political education programs. Cooperation with the government and political parties is needed to run a sustainable program. Collaboration with community organization activists is very important because they have a close relationship with the community. Activists also understand the conditions and political participation of woman in society.

\section{References}

[1] R. W. Liddle, “Deepening Democracy in Indonesia? Direct Elections for Local Leaders (Pilkada).” JSTOR, 2010 .

[2] M. Erb and P. Sulistiyanto, "Deepening Democracy in Indonesia? Direct Elections for Local Leaders (Pilkada)," Singapore ISEAS Publ., 2009.

[3] S. Desposato and B. Norrander, "The gender gap in Latin America: Contextual and individual influences on gender and political participation,” Br. J. Polit. Sci., pp. 141-162, 2009.

[4] B. Vissandjee, A. Apale, S. Wieringa, S. Abdool, and S. Dupéré, "Empowerment beyond numbers: Substantiating women's political participation," J. Int. Womens. Stud., vol. 7, no. 2, pp. 123-141, 2005.

[5] P. Parvin and B. Saunders, "The ethics of political participation: engagement and democracy in the $21 \mathrm{st}$ century," Res Publica, vol. 24, no. 1, pp. 3-8, 2018.

[6] B. Allah-Mensah, "11 Women and politics in Ghana, 1993-2003," Ghana One Decad. Lib. State, vol. 1956, p. $251,2007$.

[7] A. B. Turcinskaite and J. Balciunas, "Gender and Socioeconomic Influence on Civic and Political Participation as a Result of Socialization,” Int. J. Interdiscip. Civ. Polit. Stud., vol. 11, pp. 1-12, 2016. 
[8] S. Graham Davies, "Women in politics in Indonesia in the decade post-Beijing," Int. Soc. Sci. J., vol. 57, no. 184, pp. 231-242, 2005.

[9] I. W. Iskandar and Z. bin Ahmad, "Activist Women's Political Participation in East Kalimantan Governor Election 2008-2018," CCER, p. 10, 2019.

[10] M. U. Anshor, "Tantangan Kepemimpinan Perempuan di Tingkat Lokal," Yinyang J. Stud. Islam Gend. dan Anak, vol. 3, no. 1, pp. 81-88, 2008.

[11] F. Kontu, "Representasi perempuan dalam politik lokal di era otonomi daerah," Soc. J. Ilmu Adm. dan Sos., vol. 6 , no. 1, pp. 34-46, 2017.

[12] M. D. Rita, H. Yanzi, and Y. Nurmalisa, "Peranan KPU dalam sosialisasi pemilukada kepada penyandang disabilitas di kota Bandar lampung," J. Kult. Demokr., vol. 5, no. 1, 2016.

[13] A. Purwanti, "Quota law's for women in politics: Implementation in Indonesia," South East Asia J. Contemp. Business, Econ. Law, vol. 6, no. 4, pp. 28-36, 2015.

[14] J. Newman, M. Barnes, H. Sullivan, and A. Knops, "Public participation and collaborative governance," $J$. Soc. Policy, vol. 33, no. 2, pp. 203-223, 2004.

[15] K. Beauregard, "At the Intersection of Gender and Language: Why do Francophone Women have Lower Levels of Political Participation?," Am. Rev. Can. Stud., vol. 46, no. 1, pp. 74-92, 2016. 